\title{
The Effectiveness of Community Development and Environmental Protection Program in Oil and Gas Industry in Indonesia: Policy, Institutional, and Implementation Review
}

\author{
Martha Fani Cahyandito ${ }^{1}$ \\ ${ }^{1}$ Department of Management and Business, Faculty of Economics and Business, Universitas Padjadjaran, \\ Bandung, Indonesia \\ Correspondence: Martha Fani Cahyandito, Department of Management and Business, Faculty of Economics and \\ Business, Universitas Padjadjaran, Bandung, Indonesia. E-mail: cahyandito@yahoo.com
}

\author{
Received: February 4, 2017 Accepted: February 26, 2017 Online Published: February 28, 2017 \\ doi:10.5539/jms.v7n1p115 URL: http://doi.org/10.5539/jms.v7n1p115
}

\begin{abstract}
In all industries, inclusively oil and gas, Corporate Social Responsibility (CSR), including community development and environmental protection, have a significance role for the sustainability of company business. However, despite established government regulations and a large amount of company budget for the program, the big question that arises is whether these programs have been effectively addressed the social and environmental needs of surrounding communities, and whether the program succeeded in supporting the sound operation of oil and gas companies. This qualitative research is conducted by collecting data fromthe central and local governments in Indonesia, from oil and gas companies throughout Indonesia, as well as from communities near operating areas, through desk study, survey, in-depth interviews, and Focus Group Discussion (FGD). The results showed that, in general, the community development and environmental protection program have been implemented. Unfortunately, the programs have not been yet fittothe societies socio-environmental condition, have not been yet answered all communities' social, economic, environmental, and cultural issues, and have not been yet fully supported the sound operation of the company. This means that the programs have not been used effectively.
\end{abstract}

Keywords: CSR, community development, environmental protection, stakeholder needs, regulation, oil and gas

\section{Introduction}

Corporation, besides their role as business institutions, have also the role of existence as social entity (corporate citizenship) that affect and are affected by environmental conditions. Therefore, the existence of the corporation should appropriately provide public benefits, especially for the surrounding communities where these corporations pursue their business activities. One form to manifest their concern for the people and environment is to carry out the Corporate Social Responsibility (CSR), one of them through community development (comdev) and environmental protection program (Carrol \& Shabana, 2010; D'Amato et al., 2009; Crane et al., 2008; Hohnen, 2007).

In the early stages, CSR is a part of corporate efforts to obtain the social license and to increase the social acceptance towards their existence and operations. Thus, it is not wrong if the CSR program is considered to be one of the strategies for social mitigation in addition to obtaining and increasing the social acceptance of the company (Morrison, 2014; Ugurlar, 2011).

The comdev program in oil and gas industry has been regulated through various regulations, including Law No. 22 of 2001 on Oil and Gas, Government Regulation No. 42 Year 2002 on Regulatory Agency for Upstream Oil and Gas Business Activities, Government Regulation No 35 of 2004 on Upstream Oil and Gas, as well as Governance Guidance for Regulatory Agency for Upstream Oil and Gas Business Activities No. 017/PTK/III/2005 on Public Relations and Community Development. In relation to the environmental aspects, the oil and gas industry must also comply with the Act No. 32 of 2009 on the Environmental Protection and Management, in which the oil and gas industry must pay attention to aspects of environmental and social impact.

The existence of the Ministry of Energy and Mineral Resources that oversees the activities of extractive industries including oil and gas shall encourage existing industries to maximize their positive impact on the 
environment and society, both socially, economically, and environmentally (Sulistyono, 2015; Spence, 2010). In general, comdev programs in the oil and gas industry have been implemented. However, many challenges and problems have been occuring in realizing the effective and sustainable CSR, including comdev and environmental protection. This study (1) explores the different regulations on CSR in Indonesia and other countries, (2) identifies problems in the implementation of CSR programs, and (3) explores the effectiveness of comdev and environmental protection programs of oil and gas companies in Indonesia related to regulation and dynamics of social, economic, environmental, and cultural. The research results are beneficial for the oil and gas companies to develop strategies to better manage their community development and environmental protection programs to meet the expectations of the stakeholders.

\section{Literature Study}

\subsection{Concept of Corporate Social Responsibility (CSR)}

CSR is an essential element of a sustainable business framework, which includes the economic, environmental, and socio-cultural aspects. CSR is an essential process in the management of costs and benefits of business activities with the stakeholders, both internally (employees, shareholders, and investors) and externally (regulatory bodies, members of the public, civil society groups, and other companies), which are not only limited to the concept of charity, but the concept is very broad and is not static and passive, but CSR is becoming the rights and also obligations which is shared between stakeholders (Raupp et al., 2011; Crowther \& Aras, 2008).

Etymologically, the corporate is defined as a business entity that has legal entity, social is defined as matters relating to the community, and responsibility is defined as a form of liability (Raupp et al., 2011; Crowther \& Aras, 2008).

In Indonesia, to date, there are still many differences in understanding the concept of CSR, in which many agencies and industry provides different insight and scope to look at the concept of CSR (Jalal, 2009). Essentially, CSR is a form of social responsibility that maturates as a manifestation of good corporate governance. On this side, CSR is seen as an application of corporate existence as a social element (corporate citizenship), which is part of a business ethics. In this case, the implementation of CSR refers to a broader concept and globally. In addition to the above, there are three basic principles, which are important to consider in the implementation of CSR (Tripple Bottom Lines of CSR), in which this principle should be a thorough understanding of the application of CSR programs, namely (Idowu et al., 2014; Elkington, 2000):

- Profit means that the basic concept remains in search of economic benefits to still be able to operate and grow

- People should still have the means of social concern for the welfare of mankind.

- $\quad$ Planet means caring for the environment and sustainability of biodiversity.

This 3P principle can also be coupled with another P that is Procedure, which means that the CSR programs remain in accordance with the agreed procedures, which is in such efficient and uncomplicated way that satisfies many (Cahyandito \& Yulianita, 2011).

CSR can simply be defined as a concept, which requires the company to meet and consider the interests of stakeholders while seeking for profit. Stakeholders in question include shareholders, employees (workers), customers, local communities, government, non-governmental organizations (NGOs), and others. Social responsibility is the reciprocal act of companies to the community and the surrounding environment because the company has been taking advantages from the community and the surrounding environment, which in the process of taking those advantages, often the companies are causing environmental damage or other social impacts (Cahyandito, 2012, 2005).

Meanwhile, ISO 26000 mention CSR as a social responsibility (SR), which is defined as an organization's responsibility for the impact of decisions and activities on society and the environment, through transparent and ethical behavior, which is (ISO 2010):

- Consistent with sustainable development and social welfare;

- Taking into account the interests of stakeholders;

- Under applicable law and consistent with international norms;

- Integrated in all activities of the organization, in this sense covers both activities, products and services.

In ISO 26000, there are seven (7) aspects of CSR, which cover issues such as corporate governance, human rights, labor, consumer, fair business, environment, and inclusion and empowerment of community. Thus, the 
issue of community development and environmental protection are part of the CSR aspect of the ISO 26000 (ISO 2010).

\subsection{Implementation and Model of CSR}

CSR implementation by each company relies heavily on the mission, culture, environment, and risk profile, as well as the operating conditions of each company. Implementation of CSR can be done according to priority based on the availability of resources owned by the company. Although there is no standard or specific practices which considered the best in the implementation of CSR, but a framework that is widespread in implementing CSR can still be formulated, based on experience and knowledge in fields such as environmental management.

Models or patterns of CSR which are commonly applied by companies in Indonesia are as follows (Saidi \& Abidin, 2004, 2004):

1) CSR can be implemented directly by the company. Companies can run their CSR program directly by theirselves by organizing social events or submit their contributions to the public without intermediaries.

2) CSR can also be carried out by the foundation or charitable organization belonging to the company or its group. The company established its own foundation or charitable organization under the company or the group, which is formed separately from the parent company but still has to be responsible to the CEO or board of directors.

3) Most companies in Indonesia implementing CSR through cooperation or in partnership with others. The company maintains its CSR through cooperation with government agencies, universities, NGOs, or consulting firms to manage funds and in carrying out its social activities.

4) Some companies join in a consortium for jointly implementing CSR. Company can co-found, become a member, or support a social institution established for specific social goals.

CSR approach, which is based on charity and humanitarian motivation, is generally done on an ad-hoc, partial, and not institutional. CSR at this level simply tends to "do good" and to "look good", doing good to make it look good. Nowadays, more and more companies do not like such a charitable approach because it is not able to increase the empowerment or the capacity of local communities. Comdev approach applied since then more and more closer to the concept of empowerment and sustainable development.

\subsection{Linkage between CSR and Comdev}

Community Development is a process designed to create the advancement of economic and social conditions of the community through active participation, which in turn will foster initiative and independency of the community itself (Cahyandito, 2012; Achda, 2006).

CSR concept is closely related to the concept of comdev, where comdev is an important part in the process of implementation of CSR activities. Meanwhile, the Environmental and Social Responsibility, as set forth in Article 74 of Law No. 40/2007 on Limited Liability Company, is a corporate compliance to existing sectoral regulations. Environmental and Social Responsibility is mandatory which in practice, companies must comply with all legislation and other regulations related to the environment, among others, Act No. 32/2009 on the Protection and Management of the Environment; Act No. 18/2008 on Waste Management, Government Regulation No. 82/2001 on Air Pollution Control.

The relationship between comdev, Environmental and Social Responsibility (ESR), and CSR can be mapped in Figure1.

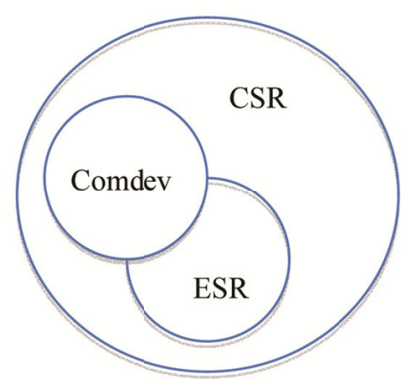

Figure 1. Linkage between Comdev, ESR, and CSR (KLH, 2011) 


\subsection{Benefits of CSR through Comdev and Environmental Protection}

\subsubsection{For Company}

Companies can contribute to improving the quality of life. Companies' attention to the public can be done by conducting activities and the making of policies that can improve the well-being, quality of life, and community competence in various fields.

Companies can also participate in environmental conservation efforts for the sake of maintaining the quality of mankind life in the long run. The company's involvement in the maintenance and preservation of the environment means that companies participating in efforts to prevent disasters and minimize the impact of disasters caused by environmental damage. With CSR, companies are expected to not only pursue short-term profits, but also contribute to improving the quality of life and the environment (especially environment in the operation areas) in the long term (Cahyandito \& Yulianita, 2011; Rudito et al., 2004).

CSR through the comdev and environmental protection and can provide many advantages, namely: (1) increased profitability for the company and better financial performance. Many large companies are implementing CSR program shows the real advantage of the increase in share value; (2) Reduce the risk of collisions with the surrounding community, because the real substance of the existence of CSR is to strengthen the sustainability of the company itself in an area, by building cooperation among stakeholders; (3) Able to increase the company's reputation that can be seen as a social marketing for the company that is also part of the corporate image building (Untung, 2008; Wahyudi \& Azheri, 2008; Susanto, 2007).

The company obtains several advantages for implementing its social responsibility, among others: to maintain and boost the company's reputation and brand image; worth getting a license to operate (social license to operate), reducing the risk of the company's business; widen access to resources; unfurled access to the market; reduce costs; improve relations with stakeholders, to improve relations with regulators; and improve motivation and productivity of employees (Susiloadi, 2008).

\subsubsection{For Government and Society}

The benefits of CSR program for the government and public are as follows (Susiloadi, 2008):

- Complementary of development programs by the government

- The problems associated with poverty, unemployment, inequality will be relatively resolved

- Utilization of the potential and local resources

- In cooperation to develop mutual benefit relationships with other parties

- $\quad$ Strengthening the capacity (individual or organisation)

- Lesson-learned process in each stage of the program

- $\quad$ Better economic life towards independency

\subsection{Regulation on CSR}

\subsubsection{Regulation on CSR in Other Countries}

As described above regarding the definition of CSR, the CSR concept is the company "initiative" and a voluntary act. It spawned two views about whether or not the regulations on CSR become a legal obligation. There is the view that if it is set up as a legal obligation then it is not in accordance with the spirit of CSR itself which is actually a company voluntary activity to do something for the community. According to AndiSyahrani, regulation of CSR in the "hard law" (i.e., Act of Public-Listed Company No. 40 of 2007 under Indonesian law) can be regarded as a backward step in the trend of global business law toward in the direction of deregulation and give more space to the efforts of "self regulation" via "soft law". Andi Syafrani also stated that there was no regulatory precedent of CSR in any country in the world (Syafrani, 2008).

On the other hand, there are also some parties who support, encourage and even arranged CSR becomes a legal obligation of the company. For instance, Friends of the Earth Europe through its Director, Fouad Hamdan representing the NGO told the European Commission that "voluntary measures will not address most of social and environmental problems related to companies' operations. We need clear rules and regulations on CSR". He also said that "voluntary initiatives can be successful in some cases but regulatory measures are necessary to ensure all corporations abide in national and international rules..". In general, the NGO urged a legalrule that binds company to carry out CSR. Almost similar as in Indonesia, not least that supports the regulation of CSR into the company's legal liability (Syahrani, 2008). 
The absence of presedent of regulatory on CSR in any country in the world like Andi Syafrani mentioned above does not mean that there is absolutely no regulation about it. The point is that there is no term CSR is explicitly required by the legislation in other countries. Some state make the rules relating to CSR are as follows (Nugroho et al., 2010):

- In the United States, as set out in the Sarbanes Oxley Act of 2002, which governs the obligations of directors in establishing company financial and performance reports as a way to improve corporate social responsibility.

- In the UK, the Companies Act version 2007 enhances and increases the director's obligation including the preparation of reports containing financial analysis that uses financial key performance indicators (Section 172 (6)) and reports that contain information related to the environment and the workers.

- In France, there is "The New Economic Regulation Law of 2001" which requires companies to always provide information about the activities of companies that have an impact on the environment and how companies consider social aspects in the company's annual reports and all of them are required to always be transparent.

- $\quad$ Additionally, what always been undertaken by developed countries is to develop incentives that encourage companies to do social investment as part of the "welfare mix" (welfare as a shared responsibility). For example, in America, the government provides tax cuts for companies that contribute to certain social groups.

Thus, what is set is not the obligation to conduct CSR directly, but rather the obligation to make a report on the company activities. In other words, what is obliged isthe report on what has been done by the company, instead of setting up what should be done by the company. This could happen because the level of commitment and awareness of the company in CSR is already high. Public awareness of the rights and participation was also better than the country of Indonesia. In Europe, if there are companies that pollute or damage the environment, the company name will be announced to the public and the public are invited to boycott the products (Nugroho et al., 2010).

However, Juniati Gunawan said that actually, it can be assured implicitly that every country around the world already have regulations that led to the practice of CSR, regardless of its form, for example, the regulation of labor (e.g., wages, rights and obligations of employees) or the environment. So even though the obligation to do CSR is not explicitly mentioned, there isstill arrangementcan be found, regarding the obligations of the company to be responsible in other areas outside the responsibility of the owners (Gunawan, 2015).

In the international level, institutions such as the OECD (Organization for Economic Cooperation and Development), ILO (International Labour Organization) and the United Nations were trying to create a framework to regulate CSR. The setting of the three institutions in the form of guidelines is voluntary. Thus, it is not legally binding; only in the form of soft law.

In addition, the International Organization of Standardization (ISO) has developed guidelines and standards for social responsibility named ISO 26000: Guidance Standard on Social Responsibility. ISO 26000 provides guidelines for a voluntary standard on social responsibility of an institution, which covers all sectors of public bodies and private entities in both the developing and developed countries. Even this does not include any law, but only kind of guideline whose validity depends on the commitment of each institution (ISO 2010).

\subsubsection{Regulation on CSR in Indonesia}

In terms of regulation, currently, Indonesia has some regulations that can be used as an implementation reference of CSR, among others: Article 33 of State Constitution, Law No. 23/1997 on Environmental Management, Law No. 22/2001 on Oil and Gas, Law No. 25/2004 on National Development Planning System, Law No. 32/2004 on Regional Government, Law No. 25/2007 on Investment, Law No. 1/2007 on Public-listed Companies, and KEP-236/MBU/2003 on Partnership Program of State-Owned Enterprises (SOEs) and SMEs. In these regulations, it is essentially implied that efforts must be made both by governments and corporations to conduct community development, both in social, educational, economic and health.

For more details, Table 1 presents the contents of some of the regulations that can be used as a reference in the implementation of CSR in Indonesia. 
Table 1. Regulations on CSR in Indonesia

\begin{tabular}{|c|c|c|}
\hline No & Regulation & Explanation \\
\hline 1 & Article 33 of State Constitution & $\begin{array}{l}\text { Article } 33 \text { of State Constitution is an Act of the most fundamental in the implementation } \\
\text { of CSR, in which all natural resources is utilized for the welfare of the people }\end{array}$ \\
\hline 2 & $\begin{array}{l}\text { Act No. } 25 \text { of } 2007 \text { on Capital } \\
\text { Investment }\end{array}$ & $\begin{array}{l}\text { Any companies or individuals as referred to Article 5, that does not meet the obligations } \\
\text { as specified in Article } 15 \text { may be subject to administrative sanctions in the form of: } \\
\text { - written warning } \\
\text { - restrictions on business activities } \\
\text { - suspension of business and / or investment facility; or } \\
\text { - revocation of business activities and / or investment facility. } \\
\text { Administrative sanctions as referred to paragraph (1) shall be issued by an authorized } \\
\text { agency or institution in accordance with the provisions of the legislation. } \\
\text { Business entities or individuals may be subject to other sanctions in accordance with the } \\
\text { provisions of the legislation. }\end{array}$ \\
\hline 3 & $\begin{array}{l}\text { Act No. } 22 / 2001 \text { on Oil and Gas, } \\
\text { Chapter VIII, Article } 40\end{array}$ & $\begin{array}{l}\text { Oil and gas industry is non-renewable strategic natural resources, which are controlled by } \\
\text { the state as well as a vital commodity that dominate the lives of many people and has an } \\
\text { important role in the national economy, which must be managed optimally to the } \\
\text { prosperity and welfare. }\end{array}$ \\
\hline 4 & $\begin{array}{l}\text { Act No. } 40 \text { Year } 2007 \text { on Public-Listed } \\
\text { Company, Article } 74\end{array}$ & $\begin{array}{l}\text { Paragraph (1). This provision aims to keep creating relationships of the company, which } \\
\text { are harmonious, balanced, and in accordance with the environment, values, norms, and } \\
\text { local culture. Referred to "the Company carries on business in the field of natural } \\
\text { resources" is a company whose business is to manage and exploit natural resources. } \\
\text { Referred to as "the Company runs its business activities relating to natural resources" is } \\
\text { the Company that does not manage and use natural resources, but its business activities } \\
\text { have an impact on the functioning ability of natural resources. } \\
\text { Paragraph (2). Clear. } \\
\text { Paragraph (3). What is meant by "sanctioned in accordance with the provisions of } \\
\text { regulations" are subjected to any form of sanctions provided for in the legislation } \\
\text { concerned. } \\
\text { Paragraph (4). Clear. }\end{array}$ \\
\hline 5 & $\begin{array}{l}\text { KEP-236/MBU/2003 Chapter II } \\
\text { Article 2, and Chapter III Article } 8\end{array}$ & $\begin{array}{l}\text { Requires all state-owned enterprises (SoE) to perform the Partnership and Community } \\
\text { Development Program through the use of funds from the profits of SOEs. The partnership } \\
\text { program with SMEs made to improve the ability of the community to become strong and } \\
\text { independent. Meanwhile the community development program is conducted through the } \\
\text { empowerment of social conditions in the business area of the SoE. }\end{array}$ \\
\hline 6 & $\begin{array}{l}\text { Act No. } 32 / 2009 \text { on the Environmental } \\
\text { Protection and Management, Article } \\
\text { 12, paragraph } 2\end{array}$ & $\begin{array}{l}\text { The environment is a unity of space, with all things, power, state, and living creatures, } \\
\text { including humans and their behavior, which affect the nature itself, the continuity of } \\
\text { livelihood, and welfare of human beings and other living creatures; } \\
\text { Environmental protection and management is a systematic and integrated efforts, which } \\
\text { are being made to preserve the environment and prevent pollution and/or environmental } \\
\text { damage that includes planning, utilization, control, maintenance, supervision, and law } \\
\text { enforcement. } \\
\text { Sustainable development is a conscious and planned effort that combines aspects of } \\
\text { environmental, social, and economic into development strategies to ensure the } \\
\text { environmental integrity as well as safety, capability, welfare, and quality of life of the } \\
\text { present generation and future generations. } \\
\text { The plan for environmental protection and management is a written plan that includes } \\
\text { potential, environmental issues, as well as the protection and management within a } \\
\text { certain time. } \\
\text { Sanction: } \\
\text { Article } 76 \\
\text { The minister, governor or regent / mayor is applying administrative sanctions to the } \\
\text { person in charge of operations and / or activities if in the supervision is found violations } \\
\text { of environmental permits. } \\
\text { The administrative sanction consisting of: } \\
\text { - a written warning; } \\
\text { - coercion of government; } \\
\text { - environmental license suspension; or } \\
\text { - revocation of environmental permits. }\end{array}$ \\
\hline
\end{tabular}




\section{Method}

The methods used to collect primary data pertaining to perceptions and expectations on the regulation plan related to community development and environmental protection on the business activities of oil and gas are in-depth interviews and focused-group discussions (FGD) with several interviewees who are selected purposively (based on position and capacity at the central government, namely the Directorate General of Oil and Gas, oil and gas industry, local government, and civil society).

Meanwhile, the secondary data includes comdev and environmental protection policy, profile of community development and environmental protection programs in the oil and gas industry, the government policies of development (central and local), the dynamics of the relationship oil and gas industry and the community, are gathered by the study of literature by studying various theories / concepts related.

The study was conducted in all regions of oil and gas operations in Indonesia with in-depth interviews and FGD with local governments, companies, and communities in the province of North Sumatra, Jambi, South Sumatra, East Kalimantan, East Java, and West Papua.

The type of data, source of data, and data collection technique can be seen in Table 2.In the meantime, the information that is collected from the in-depth interviews and FGD with resource persons is presented in Table 3.

Table 2. Type of data, source of data, and data collection technique

\begin{tabular}{|c|c|c|c|c|}
\hline No & Type of Data & Required Data & Source of Data & Data Collection Technique \\
\hline 1 & Primary data & $\begin{array}{l}\text { - Perceptions on oil and gas industry and the } \\
\text { community, } \\
\text { - Expectations regarding the oil and gas industry, } \\
\text { society and government, } \\
\text { - Data on the dynamics of the industry-community } \\
\text { relations issues } \\
\text { - Socio-economic conditions of society around oil } \\
\text { and gas industry } \\
\text { - A variety of relevant legal regulations }\end{array}$ & $\begin{array}{l}\text { Government (central and } \\
\text { local), actor of industry, } \\
\text { analysts, civil society } \\
\text { groups }\end{array}$ & Interview and FGD \\
\hline 2 & $\begin{array}{l}\text { Secondary } \\
\text { data }\end{array}$ & $\begin{array}{l}\text { - Profiles of relevant policies, } \\
\text { - Documentation of CSR program profile } \\
\text { - Evaluation results and characteristics of CSR } \\
\text { program } \\
\text { - Various documentation describing the } \\
\text { performance and the relations between oil and } \\
\text { gas industry and community }\end{array}$ & $\begin{array}{l}\text { The policy document, print } \\
\text { and electronic media }\end{array}$ & Literature study \\
\hline
\end{tabular}

Table 3. Respondent and information needs

\begin{tabular}{|c|c|c|}
\hline \multicolumn{3}{|l|}{ Respondent } \\
\hline Central and Local Government & Oil and Gas Company & Local Community \\
\hline $\begin{array}{l}\text { 1. Is the oil and gas companies operating in } \\
\text { your area has been implementing comdev } \\
\text { and environmental protection around the } \\
\text { area of operation? } \\
\text { 2. How are oil and gas companies implement } \\
\text { comdev and environmental protection in } \\
\text { the area of operation? } \\
\text { - What are the forms of programs and } \\
\text { activities? } \\
\text { - What are the areas that become the } \\
\text { company's attention in implementing } \\
\text { comdev and environmental protection } \\
\text { programs? } \\
\text { How is the process of programming the } \\
\text { comdev and environmental protection? } \\
\text { 3. How does the role of local government in } \\
\text { the preparation, implementation, } \\
\text { mentoring, monitoring and evaluation of } \\
\text { programs and activities of comdev and } \\
\text { environmental protection undertaken by } \\
\text { oil and gas companies? }\end{array}$ & $\begin{array}{l}\text { 1. In your opinion, what is driving the need for } \\
\text { comdev and environmental protection by the } \\
\text { company? } \\
\text { 2. How does the company implement comdev } \\
\text { and environmental protection programs in } \\
\text { the area of operation? } \\
\text { - What forms of programs and activities } \\
\text { undertaken? } \\
\text { - What are the areas that become the } \\
\text { company's concern in implementing comdev } \\
\text { and environmental protection programs? } \\
\text { How is the process of programming the } \\
\text { comdev and environmental protection? } \\
\text { 3. How is the involvement of communities and } \\
\text { local government in the preparation and } \\
\text { implementation of these programs and } \\
\text { activities? } \\
\text { How is the process of determining the } \\
\text { amount of budget that will be provided to the } \\
\text { programs and activities of comdev and } \\
\text { environmental protection? }\end{array}$ & $\begin{array}{l}\text { 1. Do you agree if oil and gas company is } \\
\text { obliged to carry out comdev and } \\
\text { environmental protection programs? } \\
\text { Why? } \\
\text { 2. As far as you know, have oil and gas } \\
\text { companies operating in your area been } \\
\text { implementing comdev and } \\
\text { environmental protection programs? } \\
\text { 3. How do those oil and gas companies } \\
\text { implement comdev and environmental } \\
\text { protection programs? } \\
\text { In what forms of programs and } \\
\text { activities? } \\
\text { What are the areas of concern of those } \\
\text { companies in implementing the } \\
\text { comdev and environmental protection } \\
\text { programs? } \\
\text { How is the planning process of } \\
\text { comdev and environmental protection } \\
\text { program? }\end{array}$ \\
\hline
\end{tabular}


4. How does the role of local government in controlling the level of compliance of the oil and gas companies implement the obligation to carry out comdev and environmental protection?

5. What has the local government done when the oil and gas companies do not carry out the comdev and environmental protection?

6. Is the comdev and environmental protection programs by oil and gas companies have been synergistic with the program and activities of the local government?

7. How is the role of local government in managing the budget of comdev and environmental protection program by oil and gas companies?

8. What are problems that arise in the implementation of comdev and environmental protection programs by oil and gas companies?

9. How is the ideal implementation of comdev and environmental protection?

10. Is there any regulation both at the level of district/city or province that regulates the implementation of comdev and environmental protection programs?

11 . Is regulation related to the implementation of comdev and environmental protection programs in the oil and gas industry required?

12. If required, what are the issues that need to be regulated?

13. What rewards (incentives) and punishment (sanctions) should be given to companies that carry out or does not carry out the obligation to perform comdev and environmental protection programs?
5. How is the management of these programs and activities carried out? Where the role of communities and local government in the management of the program?

6. How about the budget management?

7. What about the role of local government in the implementation of comdev and environmental protection programs in the oil and gas industry?

8. Is the program of comdev and environmental protection that has been implemented so far had a positive impact on the company's relationship with the community?

9. Are there any obstacles that companies face in conducting operations related to the relationship with the community and local government?

10. What are problems that arise in the implementation of comdev and environmental protection programs by companies?

11. How should the comdev and environmental protection programs be implemented in the community?

12. What about the regulation of comdev and environmental protection programs in oil and gas companies? Is it adequate?

13. What should be regulated and not regulated in the regulation of comdev and environmental protection in oil and gas companies?

14. Would you agree when there is penalty for oil and gas companies who do not want to implement comdev and environmental protection programs?

15. What sanctions are appropriate for oil and gas companies that are not willing to implement the program of comdev and environmental protection?

16. What incentives should be given to companies that have implemented comdev and environmental protection programs properly?
4. In your opinion, is the program effective?

5. What is the role of local government in the coordination and supervision of the program, whether it is feasible and effective?

6. What are problems that arise in the implementation of comdev and environmental protection programs by oil and gas companies?

7. Do you think that regulation related to the implementation of comdev and environmental protection programs in the oil and gas industry is necessary?

8. If necessary, what matters need to be regulated?

9. What rewards (incentives) and punishment (sanctions) should be given to companies that carry out ot not carry out the comdev and environmental protection programs?

10. What are your expectations related to comdev and environmental protection programs of oil and gas companies?

\section{Findings and Discussion}

\subsection{Policy and Institutional Issues}

The implementation of comdev and environmental protection programs, in general, is also faced with the issue of regulations and institutions. Things that lie behind it, among others, the lack of operational policies that guide the implementation of community development and environmental protection programs, especially in the oil and gas industry.

\subsubsection{Philanthropic-Oriented Regulation}

In Indonesia, there are already central government regulations which are derivativesof the Act of Public-Listed Companies No. 40 of 2007, namely in the form of Government Regulation No. 47 Year 2012 on Social and Environmental Responsibility of Public-Listed Companies. This government regulation emphasis on three main points, namely obliging the CSR planning, allocation of funds, and reporting of CSR activities, as well as its accountability to the General Meeting of Shareholders (GMS). However, this regulation does not further operationally explain about the implementation of the program of social and environmental responsibility.

Various local government regulations (Perda) associated with CSR are also many emerging in recent years. Among others are West Java Governor Regulation No. 30 Year 2011 on Facilitating the Implementation of Environmental and Social Responsibility in West Java; East Java Provincial Regulation No. 4 Year 2011 on Corporate Social Responsibility, Governor Regulation of Lampung No. 30 Year 2011 on Guidelines for the Management of CSR/Partnership and Comdev Program in Lampung Province; Jambi Provincial Regulation No. 
6 Year 2013 on Corporate Social Responsibility; and Provincial Regulation of East Kalimantan No. 3 Year 2013 on Social and Environmental Responsibility as well as Partnership and Community Development Program for the Public-Listed Companies.

At the level of districts/cities, there are Mayor Regulation of Cilegon No. 3 of 2011 on the Establishment of Organization and Work Procedure for Cilegon Corporate Social Responsibility (CCSR) at Cilegon City; Regent Decree of Jombang No. 188.4.45/29/415.10.10/2011 on the Coordination Team for Program Planning ofCorporate Social Responsibility_Partnership and Community Development Program in Jombang, and Regent Decree No. 10/02.188.3/HK/VII/2006 on Guidelines for Implementation of CSR in East Kutai then revised through Regent Decree No. 27 of 2012 on Implementation of Corporate Responsibilities in East Kutai Regent.

If we take a closer look, essentially, the regulations regarding the CSR only emphasizes philanthropic activities (not yet using a holistic approach), and giving more interests on economicaspect. But how the program became part of the social and environmental risk mitigation from the impact of the industry has not yet been noticeable.

\subsubsection{Implementation Guideline}

Another problem is the absence of provisions that could serve as guideline/guidance in the implementation of comdev and environmental protection programs, in this case, especially in the oil and gas industry. Policies on social and environmental responsibility is merely juridical recognition that this program is a legal obligation, but how those obligations should be implemented, still there is no further arrangement, even regulations which contain the general principles and/or common standards that can be used as a benchmark for an objective assessment though, no provision has been set up.

Exactly at this point, there is a lack of legal aspect, which causes uncertainty in the implementation of comdev and environmental protection programs in the oil and gas industry. As a result of this, at the end, the implementation of the program depends on the good faith and creativity of program implementers.

\subsubsection{Clear Roles and Functions of Institution}

Another issue, which is associated with the ineffectiveness of the program, is the lack of clarity of the roles and functions of each institution in comdev and environmental protection programs carried out by the oil and gas industry. In fact, as stated in Article 76 paragraph (1) of Act No. 35 of 2004 on Oil and Gas Upstream Business states that "local community development activities by the contractor shall coordinate with the local government".

These conditions led to several things, including:

a. Overlapping of authority and program between government/local government and the oil and gas industry

b. Comdev and environmental protection programs are frequently used for certain political interests.

c. Motive of local government officers to treat CSR program with a project approach

d. High expectation of magnitude and formof the program

e. No "uniformity" of understanding of CSR programs as well as comdev and environmentalprotection (in this case, including the scope and target of the program)

f. Claims regarding the transparency of program management (governance).

g. Dynamics of local condition and politics lead to a variety of local regulations that are sometimes contradictory with the objectives of the CSR program and the local investment climate in the oil and gas industry.

\subsection{Implementation Issues}

CSR through comdev and environmental protection programs in the oil and gas industry has a tremendous potential in supporting the achievement of sustainable development goals when its management is conducted in an organized, systematic, and focused in order to achieve community independency and prosperity. But unfortunately, this incredible potential has not been managed properly due to policy, institutional, some implementation issues.

\subsubsection{Matching with Society Socio-Economic Condition}

Although budgets and resources for the programs have been allocated, unfortunately the program has not matched with the socio-economic conditions of society. As a result thereof, the issue of poverty, unemployment, limited public infrastructure, social unrest around the area of oil and gas operations, still happen. On the other 
hand, problems on company's operation/production are also faced by the oil and gas industry as a result of occuring social problems.

\subsubsection{Top-Down and Project-Based Program}

These problems occur in connection with the management of the program that is still using the "top-down" pattern. This is reflected in the form of comdevprograms that are typically project-based and communities are treated only as objects or recipients. In this context, the program is responsive to the claims or demands of society. The program has not been designed systematically and sustainably.

\subsubsection{Social Mapping and Community Involvement}

In addition, the programs implemented by the oil and gas companies are not yet in accordance with the conditions and the real needs of society and just toucheda few number of societies, namely people who are on the top layer. More often, the programs are not yet based on the results of social mapping in the community. This is due to the program planning that does not involve the community engagement so that the aspirations of the people cannot be accommodated in these programs. Consequently, not only the program result is ineffective and does not matched withthe intended goals, but furthermore, the program implementation often leads to conflicts among communities and between communities and companies.

Public participation in comdev and environmental protection is still low. The impact of oil and gas activities on local employment and community empowerment is still low. The comdev program that has not been in accordance with the needs of society causes this.However, some oil and gas companies have been involvingtheir stakeholders, such as community involvement through forum ofMusrenbang (Development Planning Meeting) or through some other mechanism initiated by the company and the local government.

It must be bare in mind that community engagement is not an easy task. The high expectations of the public to the company are often unlimited and always change. Some communities are also often expecting an instant program, for example in the form of cash money. The waning of social capital in the community is often being a difficult factor to engage the community.

\subsubsection{Low Understanding of Oil and Gas Business, Risks, and Impact}

Another thing that also affects public perception of the oil and gas industry is the lack of knowledge about the oil and gas industry, including its impact and risks. The high risk and dense capital needed in this business is often not well understood by the public.

\subsubsection{Political Interest and Corruption}

Moreover, people are often easily influenced by certain elite interests. This challenge is compounded by the potential for horizontal conflict (between groups), which often impact on the company.

On the other hand, the rampant issue of corruption and poor public services at present has resulted in low/waning confidence in the government, so the public relies more in the company's contribution to improving the welfare. This will lead to the dependence of society to the company. Therefore, numerous social programs undertaken by the company should be targeted in efforts to achieve self-reliance of the community.

\section{Conclusion}

In general, it can be concluded that the implementation of CSR programs related to community development and environmental protection, has not been yet effective and have not been in accordance with the needs and conditions of the community.

This happens because of some government policy issues, institutionalisation issues including the lack of program managers who understand the community development and environmental protection programs, as well as the issue of program management that has not been yet well established.

Associated with these constraints, a set of policies on the implementation of community development and environmental protection is needed so that the program is more effective as expected. The need of oil and gas industry to provide legal certainty and operational implementation of this program is required. The understanding of the concept of CSR in community development and environmental protection should also be given to program planners and implementers, as well as to the government and society.

\section{References}

Achda, B. T. (2006). The Sociological Context of Corporate Social Responsibility Development and Implementation in Indonesia. Journal of Corporate Social Responsibility and Environmental Management, 13, 300-305. http://dx.doi.org/10.1002/csr.133 
Cahyandito, M. F. (2005). Corporate Sustainability Reporting-A New Approach for Stakeholder Communication. Remagen-Oberwinter, Germany: Verlag Kessel.

Cahyandito, M. F. (2012). Coupling Corporate Social Responsibility into Millennium Development Goals is a Mere Wishful Thinking? Journal on Management and Sustainability, 2(1), 67-74. http://dx.doi.org/10.5539/jms.v2n1p67

Cahyandito, M. F., \& Yulianita, N. (2011). Audit CSR for Business Sustainability: Case Study at Pertamina Kamojang Indonesia. Proceeding at The Eleventh International Conference on Knowledge, Culture and Change, Madrid, June 15-17, 2011.

Carroll, A. B., \& Shabana, K. M. (2010). The Business Case for Corporate Social Responsibility: A Review of Concepts, Research and Practice. International Journal of Management Reviews, 85-105. http://dx.doi.org/10.1111/j.1468-2370.2009.00275.x

Crane, A., McWilliams, A., Matten D., Moon J., \& Siegel, Donald, S. S. (2008). The Oxford Handbook of Corporate Social Responsibility (1st ed.). New York: Oxford University Press.

Crowther, D., \& Aras, G. (2008). Corporate Social Responsibility. Ventus Publishing ApS. Retrieved from BookBooN.com

D’Amato, A., Henderson, S., \& Florence, S. (2009). Corporate Social Responsibility and Sustainable Business: A Guide to Leadership Tasks and Functions. North Carolina: CCL Press.

Elkington, J. (2000). Cannibals with Forks: The Triple Bottom Line of 21st Century Business. Journal of Business Ethics, 23(2), 229-231. http://dx.doi.org/10.1023/A:1006129603978

Gunawan, J. (2015). Corporate Social Disclosures in Indonesia: Stakeholders' Influence and Motivation. Social Responsibility Journal, 11(3), 535-552. http://dx.doi.org/10.1108/SRJ-04-2014-0048

Hohnen, P. (2007). Corporate Social Responsibility: An Implementation Guide for Business. International Institute for Sustainable Development (IISD), Monitoba Canada.

Idowu, S. O., Kasum, A. S., Mermod, A. Y. (2014). People, Planet and Profit: Socio-Economic Perspectives of CSR. London: Routledge.

International Standard Organization (ISO). (2010). ISO 26000: Guidance on Social Responsibility.

Jalal. (2009). Kesalahpahaman Seputar Tanggung Jawab Sosial Perusahaan. Power Point Diskusi Lets CSR di Institut Pertanian Bogor, 23 Mei 2009.

KLH (Kementerian Lingkungan Hidup Republik Indonesia) /Ministry of Environment of the Republic Indonesia. (2011). Pedoman CSR Bidang Lingkungan.

Morrison, J. (2014). The Social License: How to Keep Your Organization Legitimate. London, UK: Palgrave Macmillan.

Nugroho, Y., Tanaya, J., Widiyanti, T., \& Permana, A. H. (2010). Country Profile: Indonesia. In W. Visser \& N. Tolhurst (Eds.), The World Guide to CSR: A Country-by-Country Analysis of Corporate Sustainability and Responsibility. Sheffield UK: Greenleaf Publishing. https://doi.org/10.9774/GLEAF.978-1-907643-09-5_28

Raupp, J., Jarolimek, S., \& Schultz, F. (2011). Handbuch CSR: KommunikationswissenschaftlicheGrundlagen, disziplinäreZugänge und methodischeHerausforderungenMitGlossar. Wiesbaden: VS Verlagfür Sozialwissenschaften. https://doi.org/10.1007/978-3-531-92639-1

Rudito, B., Budimanta, A., \& Prasetijo, A. (2004). Corporate Social Responsibility: Jawaban bagi Model Pembangunan Indonesia Masa Kini. Jakarta, Indonesia Center for Sustainable Development (ICSD).

Saidi, Z., \& Abidin, H. (2004). Corporate Social Responsibility: Alternatif bagi Pembangunan Indonesia. ICSD, Jakarta.

Saidi, Z., \& Abidin, H. (2004). Menjadi Bangsa Pemurah: Wacanadan Praktek Kedermawanan Sosial di Indonesia. Jakarta: Piramedia.

Spence, D. B. (2010). Corporate Social Responsibility in the Oil and Gas Industry: The Importance of Reputational Risk. Chicago-Kent Law Review, 86(1). Symposium on Energy Law, Article 4, pp. 59-85.

Sulistyono. (2015). Kegiatan Usaha Industri Migas Hubungannya dengan Dampak dan Kelestarian Lingkungan Hidup. Journal of Forum Teknologi, 5(2), 23-30.

Susanto, A. B. (2007). Corporate Social Responsibility. The Jakarta Consulting Group, Jakarta. 
Susiloadi, P. (2008). Implementation Corporate Social Responsibility to Support Sustainability Development. Spirit Publik, 4(2), 123-130.

Syafrani, A. (2008). Paradoks Regulasi CSR. Retrieved from https://www.academia.edu/25798952/Paradoks_Regulasi_CSR

Ugurlar, N. P. (2011). Corporate Social Responsibility and Competitive Advantage: Consumer perceptions of corporate social responsibility practices. Mannheim: LAP Lambert Academic Publishing.

Untung, H. B. (2008). Corporate Social Responsibility. Jakarta: Sinar Grafika.

Wahyudi, I., and B. Azheri. (2008). Corporate Social Responsibility: Prinsip, Pengaturan dan Implementasi. Malang: In-Trans Publishing.

\section{Copyrights}

Copyright for this article is retained by the author(s), with first publication rights granted to the journal.

This is an open-access article distributed under the terms and conditions of the Creative Commons Attribution license (http://creativecommons.org/licenses/by/4.0/). 